\title{
PENGARUH PIJAT BAYI DENGAN TERAPI BUNGA LAVENDER TERHADAP PEMENUHAN KEBUTUHAN TIDUR NEONATUS DI POSYANDU MELATI MOJOROTO KEDIRI
}

\author{
Sri Kasmiatun
}

\begin{abstract}
Sleeping are unconscious which still work order of succesion siclic and can be brain and body work difference. Sleeping disturb is happened young people but it child and baby disturb happenend. Neonatus until three month to need sleeping time more 20 hour. The purpose of this observation was to know whether there any effect of lavender aroma teraphy baby massage toward neonatus sleeping necesity at the work region of posyandu Melati Mojoroto Kediri. The observation was the pre experiment by using one group pre post test one disign approach. Independen variable is lavender aroma teraphy body massage and dependent variable sleeping necesity, experiment instrument with observation. The population in the observation as many as 13 neonatus and the number of samples as many as 13 neonatus with the sample taking technique was using total sampling. The result was gotten the observation was almost a half 9 neonatus $(69,23 \%)$ experienced can't sleeping necesity before lavender aroma teraphy body massage and and most 12 neonatus (92\%) can be sleeping necesity after lavender aroma teraphy baby massage. By using t-test was gotten the result, $\rho$ value $=0,001<\alpha=0,05$, so Ho was rejected. It meant that there was lavender aroma theraphy baby massage toward sleeping necesity at the work region of Posyandu melati Mojoroto Kediri in 2011. It was suggested to mothers to do baby massage at regular time with lavender aroma teraphy so can sleeping neonatus necesity so baby growt age harmony.
\end{abstract}

\section{Kata kunci : baby massage, lavender aroma teraphy, neonatus sleeping necesity.}

Pendahuluan

Gangguan tidur ternyata tidak hanya terjadi pada orang dewasa saja, tetapi gangguan ini bisa terjadi pada bayi dan anak-anak. Seorang bayi yang baru lahir atau sampai usia 3 bulan akan memerlukan waktu untuk tidur hampir seharian atau lebih dari 20 jam. Bila bayi terbangun setiap malam setiap harinya atau pola tidurnya sama dengan orang dewasa atau mempunyai temperamen yang buruk karena kurang tidur berarti bayi mempunyai gangguan tidur yang perlu diatasi.(Wong, 2003). Untuk meningkatkan konsentrasi dan membuat bayi tidur lebih lelap ada tekhnik pijat bayi yang dapat dilakukan oleh ibu di rumah. Pemijatan merupakan kegiatan yang menyenangkan yang dapat membuat ibu kontak dengan bayinya baik secara fisik maupun emosi, pengalaman pijat pertama yang dialami manusia adalah ketika lahir, saat melewati jalan lahir ibu. (Roesli, 2007). Pemijatan disertai dengan pemberian aroma terapi merupakan stimulan yang tepat untuk membuat bayi tidur dengan nyenyak. Aroma terapi akan menyebarkan molekul-molekul yang menyebarkan wangi dan menstimulasi susunan syaraf pusat yang berguna untuk relaksasi dan pengobatan. (Tim Gaya Hidup Sehat, 2010). Untuk membuat tidur lebih nyenyak pemberian aroma terapi dengan aroma bunga lavender membuat bayi nyaman, namun ibu-ibu seringkali tidak mengetahui manfaat dari pijat bayi disertai dengan pemberian aroma terapi bunga lavender ini sehingga ketika bayi mempunyai masalah tidur ibu kesulitan untuk menanganinya ( 2011)

Studi pendahuluan yang dilakukan peneliti di wilayah kerja Posyandu melati Mojoroto Kediri pada tanggal 2 Mei 2011 
didapatkan 30 orang bayi sering terbangun dan menangis di malam hari. Diantaranya 26 bayi $(86,7 \%)$ menunjukkan reaksi sering terbangun dan menangis walau sudah diberikan susu dan pampers dalam kondisi kering. Sedangkan 4 bayi $(13,3 \%)$ tidak menunjukkan reaksi menangis tetapi sering terbangun.

Bayi baru lahir biasanya tidur selama 16-20 jam yang dibagi menjadi 4-5 periode. Pola tidur bayi masih belum teratur, karena jam biologis yang belum matang. Tetapi perlahan-lahan akan bergeser sehingga lebih banyak waktu tidur di malam hari dibandingkan dengan siang hari. (Wong, 2003). Pada bayi dan anak-anak, tidur adalah saat saat untuk mengoptimalkan laju tumbuh kembang badan. Umumnya bayi tidak mengalami masalah tidur. Artinya, mereka bisa dengan cepat terpulas, dan tidak mudah terbangun. Namun, terkadang ada juga yang sebaliknya. Sulit tidur, dan mudah terbangun. Bagi bayi, tidur memiliki peran ganda. Selain memberi kesempatan untuk mengistirahatkan tubuh, juga untuk meningkatkan proses metabolisme, yakni proses pengolahan pangan menjadi energi yang dibutuhkan" papar Jodi Mindell $\mathrm{PhD}$, pakar tidur anak di Children's Hospital of Philadelphia seperti dikutip Parents. Karena itu, saat tidur pertumbuhan fisik anak terpacu.

Pijat bayi merupakan salah satu cara yang dilakukan ibu untuk membantu bayi terpenuhi kebutuhan tidurnya. Dengan pijat bayi maka bayi akan merasa tenang rileks sehingga bayi akan tidur lebih lama, dengan penambahan aroma terapi maka kualitas tidur bayi akan terpenuhi. Dampak jika bayi kurang tidur kemampuan motorik tidak optimal, daya tahan tubuh menurun, gangguan pertumbuhan dan perkembangan, kegemukan atau obesitas, muncul gangguan emosi (2011). Aroma terapi akan menyebarkan molekul-molekul yang menyebarkan wangi dan menstimulasi susunan syaraf pusat yang berguna untuk relaksasi dan pengobatan. (Tim Gaya
Hidup Sehat, 2010). Untuk membuat tidur lebih nyenyak pemberian aroma terapi dengan aroma bunga lavender membuat bayi nyaman. Untuk itu adakah pengaruh pijat bayi dengan terapi bunga lavender terhadap pemenuhan kebutuhan tidur neonatus.

Penelitian ini bertujuan untuk mengetahui pengaruh pijat bayi dengan terapi bunga lavender terhadap pemenuhan kebutuhan tidur neonatus di Posyandu Melati Mojoroto Kediri

\section{Metodologi Penelitian}

Desain penelitian yang digunakan adalah penelitian pre eksperimen dengan menggunakan model one group pra-test post test desain tipe penelitian ini adalah dengan cara melibatkan satu kelompok subjek. Populasi Populasi pada penelitian ini adalah seluruh neonatus yang berada di wilayah kerja posyandu Melati Mojoroto Kediri sebanyak 13 neonatus . Teknik sampling yang digunakan dalam penelitian ini adalah teknik total sampling. Variabel Independen dalam penelitian adalah pijat bayi dengan terapi aroma bunga lavender dan Variabel dependennya pemenuhan kebutuhan tidur bayi. Analisa data dengan menggunakan t-test untuk mengetahui adanya pengaruh antara variabel independen dan variabel dependen. Derajad ditentukan $\alpha: 0,05$ dan bila $p \leq \alpha$ maka ada pengaruh antara variabel independen dan dependen .Teknik pengolahan data statistikal dengan menggunakan software Statistical Product and Service Solution (SPSS ) versi 16

\section{Hasil Penelitian}
1. Pemenuhan tidur neonatus sebelum dilakukan pijat bayi dengan aroma terapi bunga lavender

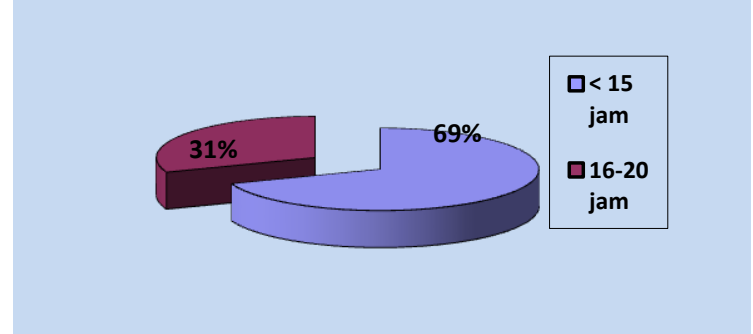


Gambar 1 Pemenuhan kebutuhan tidur neonatus sebelum dilakukan pijat bayi dengan aroma terapi bunga lavender di Wilayah Kerja Posyandu Melati Mojoroto Kediri

Berdasarkan gambar 1 menunjukkan bahwa hasil penelitian pemenuhan tidur neonatus sebelum dilakukan pijat bayi dengan aroma terapi bunga lavender didapatkan sebagian besar kebutuhan tidur neonatus tidak terpenuhi yaitu 9 orang $(69 \%)$

2. Pemenuhan tidur neonatus setelah dilakukan pijat bayi dengan aroma terapi bunga lavender

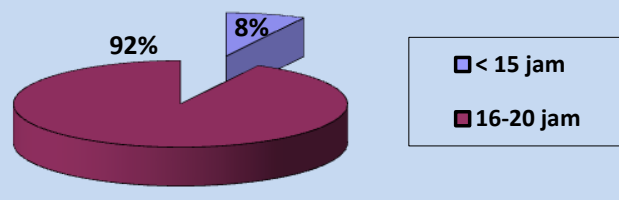

Gambar 2 Pemenuhan kebutuhan tidur neonatus setelah dilakukan pijat bayi dengan aroma terapi bunga lavender di Wilayah Kerja Posyandu Melati Mojoroto Kediri

Berdasarkan gambar 2 menunjukkan bahwa hasil penelitian pemenuhan tidur neonatus setelah dilakukan pijat bayi dengan aroma terapi bunga lavender didapatkan sebagian besar kebutuhan tidur neonatus terpenuhi yaitu 12 orang $(92 \%)$.

\section{Tabulasi Silang Observer dengan Pemenuhan Kebutuhan Tidur Neonatus Setelah Pijat Bayi dengan Aroma terapi Bunga Lavender}

Tabel 1 Tabulasi Silang observer dengan pemenuhan kebutuhan tidur neonatus setelah pijat bayi dengan aroma terapi bunga lavender pada neonatus di wilayah kerja Posyandu Melati Mojoroto Kediri

\begin{tabular}{lllllll}
\hline \multirow{2}{*}{} & \multicolumn{3}{c}{ sebelum dipijit } & & \\
\cline { 2 - 5 } & \multicolumn{3}{c}{ Tidak } & Terpenuhi & & \\
\cline { 2 - 5 } & terpenuhi & & & & \\
\cline { 2 - 5 } Ibu & 0 & 0 & 5 & 38,46 & 5 & 38,46 \\
Nenek & 0 & 0 & 2 & 15,38 & 2 & 15,38 \\
Pembantu & 1 & 7,7 & 3 & 23,07 & 3 & 23,07 \\
Suami & 0 & 0 & 3 & 23,07 & 3 & 23,07 \\
\hline Total & 1 & 7,7 & 4 & 30,77 & 13 & 100 \\
\hline
\end{tabular}

Berdasarkan tabel 1 menunjukkan 1 responden $(7,7 \%)$ yang tidak terpenuhi kebutuhan tidurnya, yang melakukan observer adalah pembantu.

Dari hasil uji $t$ - test diketahui nilai $\mathrm{t}$ sebesar -4,382 dengan derajat kebebasannya adalah 12 dan nilai p value 0,001. Signifikasi hubungan menggunakan nilai $p$ - value $<\alpha$ dengan tingkat kesalahan 0,05 . Karena nilai $p 0,001<0,05$, maka $\mathrm{H} 0$ ditolak dan H1 diterima yang berarti bahwa ada pengaruh pijat bayi dengan aroma terapi bunga lavender terhadap pemenuhan kebutuhan tidur neonatus di Wilayah Kerja Posyandu Melati Mojoroto Kediri

\section{Pembahasan}

A. Pemenuhan kebutuhan tidur neonatus sebelum pemijatan dengan aroma terapi bunga lavender

Dari hasil penelitian pada gambar 1 menunjukkan bahwa kebutuhan tidur neonatus tidak terpenuhi yaitu sebanyak 9 responden $(69 \%)$.

Gangguan tidur ternyata tidak hanya terjadi pada orang dewasa saja, tetapi gangguan ini bisa terjadi pada bayi dan anak-anak. Seorang bayi yang baru lahir atau sampai usia 3 bulan akan memerlukan waktu untuk tidur hampir seharian atau lebih dari 20 jam. Bila bayi terbangun setiap malam setiap harinya atau pola tidurnya sama dengan orang dewasa atau mempunyai temperamen yang buruk karena kurang tidur berarti bayi mempunyai gangguan tidur yang perlu diatasi (Wong, 2003). Pada minggu-minggu pertama bayi masih beradaptasi 
dengan lingkungannya sehingga mudah sekali terbangun (Roesli, 2007)

Tidak terpenuhinya kebutuhan tidur pada neonatus dapat dipengaruhi dari umur. Pada masa neonatus dalam mingguminggu pertama, bayi akan terlihat tidak aktif, bayi akan peka terhadap rangsang dari luar daripada dulu ketika masih di dalam rahim sehingga bayi akan lebih mudah terbangun, proses adaptasi dengan lingkungan mengakibatkan bayi tidak terpenuhi kebutuhan tidurnya.

Selain itu pendidikan ibu bayi juga sangat mempengaruhi kebutuhan tidur bayi. Pengetahuan yang memadai akan mempengaruhi sikap seseorang dalam berperilaku (Azwar, 2003).

Pendidikan dan pengetahuan responden tentang pemenuhan tidur bayi yang kurang dapat berpengaruh terhadap tindakan yang akan dilakukan. Ibu kadang melakukan tindakan yang tidak sengaja mengganggu tidur bayi seperti membangunkan karena merasa bayi waktunya mandi atau minum walaupun sebelumnya bayi masih cukup kenyang. Seringnya bayi bangun menyebabkan bayi rewel dan kebutuhan tidurnya tidak terpenuhi.

Selain pendidikan, pekerjaan ibu juga berpengaruh terhadap kebutuhan tidur bayi, dari tabel 4.3 didapatkan $8(61,54 \%)$ bayi yang kebutuhan tidurnya tidak terpenuhi ibunya bekerja sebagai swasta.

Menurut Effendi, (2011) seorang yang bekerja akan menghabiskan 75\% waktunya di luar rumah.

Seorang ibu yang tidak mendampingi bayinya secara penuh dan lebih banyak bekerja akan mengurangi kontak langsung dengan bayi, tentunya ibu yang bekerja akan lebih banyak waktunya di luar rumah dibandingkan dengan bayi apalagi jika jarak tempat kerja dengan rumah sangat jauh maka secara otomatis ibu akan kesulitan untuk sesering mungkin kontak dengan bayi, bayi pada minggu-minggu awal memerlukan kehangatan, dan perhatian penuh dari ibu karena pada masa ini bayi masih beradaptasi dari yang sebelumnya di dalam rahim dengan situasi di luar rahim, kurangnya kontak dengan bayi mengakibatkan hubungan kedekatan perasaan anak-ibu terganggu hal ini menyebabkan bayi menjadi sering terbangun dalam tidurnya, bayi akan mudah rewel sehingga mengganggu pertumbuhan dan perkembangannya.

\section{B. Pemenuhan kebutuhan tidur neonatus setelah pemijatan dengan aroma terapi bunga lavender}

Dari hasil penelitian pada gambar 2 menunjukkan bahwa kebutuhan tidur neonatus terpenuhi yaitu sebanyak 12 responden $(92 \%)$.

Pada minggu ketiga, bayi akan terlihat lebih aktif, gerakan lengan dan tungkai menjadi lebih terarah dan halus, reaksi terhadap rangsang yang diberikan lebih memadai, dan sudah dapat tersenyum (Wong, 2003).

Untuk meningkatkan konsentrasi dan membuat bayi tidur lebih lelap ada tekhnik pijat bayi yang dapat dilakukan oleh ibu di rumah. Pemijatan merupakan kegiatan yang menyenangkan yang dapat membuat ibu kontak dengan bayinya baik secara fisik maupun emosi, pengalaman pijat pertama yang dialami manusia adalah ketika lahir, saat melewati jalan lahir ibu. (Roesli, 2007). Pemijatan disertai dengan pemberian aroma terapi merupakan stimulan yang tepat untuk membuat bayi tidur dengan nyenyak.

Ketika bayi mulai aktif maka banyak sekali memerlukan tenaga untuk pergerakan, peregangan otot-otot bayi yang sebelumnya di dalam rahim ibu bergerak secara minimal sekarang bayi mulai bisa menggerakkan tangan dan kaki lebih leluasa tentunya bayi akan mengalami ketegangan pada otot atau bahkan capek sehingga pemberian pijat bayi disertai pemberian aroma terapi bunga lavender membuat bayi relaksasi yang akhirnya dapat membuat bayi tidur nyanyak.

Setiap bayi memiliki sifat khas dan tabiat perilaku masing-masing yang 
berbeda antara bayi laki-laki dengan perempuan, bayi laki-laki akan lebih aktif dibandingkan dengan bayi perempuan. Faktor lingkungan berperan penting dalam perkembangan perilaku ini. Orangtua harus membedakan antara menyayangi dan memanjakan agar perkembangan kepribadian anak berjalan baik sejak masa bayi (Soetjiningsih, 2003).

Aktifnya bayi akan membuat bayi menjadi tidak nyenyak saat tidur, jika bayi mengalami sesuatu yang tidak nyaman pada tubuhnya bayi akan mudah terbangun dan rewel, jika ibu tidak memahami keadaan ini maka akan terjadi gangguan pada kebutuhan tidur bayi yang tentunya akan mengganggu pertumbuhan dan perkembangannya karena pada saat tidur sebenarnya merupakan pertumbuhan dan perkembangan bayi secara optimal, dengan tidur akan mengembalikan tenaga bayi yang akhernya ketika bangun bayi bisa melakukan aktivitas dengan nyaman sehingga untuk membantu bayi agar dapat nyaman saat tidur diperlukan pemberian pijat bayi yang nantinya dapat membuat tubuh bayi merasa nyaman, pijatan yang lembut disertai dengan pemberian aroma terapi lavender yang merelaksasikan tubuh bayi membuat bayi akan tidur dengan nyenyak, dalam hal ini ibu harus pandaipandai memantau perkembangan bayi sesuai dengan umurnya, setiap perubahan pada bayi harus segera dilakukan tindakan terutama jika bayi mengalami gangguan sehingga kebutuhan tidur bayi tetap terpenuhi seiring dengan pertumbuhan dan perkembangannya.

\section{Pengaruh pijat bayi dengan aroma terapi bunga lavender terhadap menenuhan kebutuhan tidur neonatus}

Pemijatan disertai dengan pemberian aroma terapi merupakan stimulan yang tepat untuk membuat bayi tidur dengan nyenyak. Aroma terapi akan menyebarkan molekul-molekul yang menyebarkan wangi dan menstimulasi susunan syaraf pusat yang berguna untuk relaksasi dan pengobatan. (Tim Gaya Hidup Sehat, 2010).

Untuk membuat tidur lebih nyenyak pemberian aroma terapi dengan aroma bunga lavender membuat bayi nyaman. Perasaan nyaman pada bayi ini menstimulasi otak untuk rileks sehingga bayi tidur nyenyak ( Ellis dan Nowlis, 2007 )

Kurang terpenuhinya istirahat tidur bayi merupakan pengalaman individual yang bersifat emosional dan subyektif yang dapat diobservasi secara langsung. Bayi akan menunjukkan reaksi rewel dan sering terbangun dari tidurnya jika dia merasakan hal yang tidak nyaman dan mengganggu tidurnya ( Sobur, 2003 ).

Berdasarkan hasil analisis data menunjukkan nilai signifikasi dengan menggunakan uji $t$ - test diketahui nilai $\mathrm{t}$ 4,382 dengan derajat kebebasannya adalah 12 dan nilai $\mathrm{p}$ - value 0,001 . Signifikasi hubungan menggunakan nilai $p$ - value < $\alpha$ dengan tingkat kesalahan 0,05 . Karena nilai $p 0,001<0,05$, maka $\mathrm{H} 0$ ditolak dan H1 diterima yang berarti bahwa ada pengaruh pijat bayi dengan aroma terapi bunga lavender terhadap pemenuhan kebutuhan tidur neonatus di Wilayah Kerja Posyandu Melati Mojoroto Kediri tanggal 20-30 Oktober 2011.

Pijat bayi dengan aroma terapi bunga lavender yang diberikan pada responden akan dapat bermanfaat untuk relaksasi. Karena pijat bayi dengan aroma terapi bunga lavender menenangkan dan menurunkan produksi hormon adrenalin yang selanjutnya akan meningkatkan daya tahan tubuh bayi. Umumnya daya tahan tubuh bayi meningkatkan 30\% setelah dipijit 2 kali selama 15 menit, hal ini sangat penting bagi kenyamanan batin, mengurangi kecemasan, dan dapat mencegah terhadap terjadinya gangguan psikologis (Tim gaya hidup sehat, 2010).

Pada proses pijat bayi dengan aroma terapi bunga lavender, aroma terapi akan menyebarkan molekul-molekul yang menyebarkan wangi dan menstimulasi 
susunan syaraf pusat yang berguna untuk relaksasi dan pengobatan. Untuk membuat tidur lebih nyenyak pemberian aroma terapi dengan aroma bunga lavender membuat bayi nyaman proses ini dapat tercapai kalau saat memijat disertai dengan komunikasi yang hangat antara ibu dan bayi. Ibu juga harus mengetahui kapan waktu yang tepat untuk memulai pemijatan, ketika bayi dalam keadaan mengantuk, lapar atau terlalu kenyang bayi mungkin akan menolak untuk dilakukan pemijatan yang akhirnya akan membuat pemijatan ini tidak memberikan hasil yang optimal. Demikian juga kondisi ibu harus benar-benar sehat sehingga saat melakukan pijat dengan bayi, ibu dapat melaksanakannya dengan baik.

Pijat bayi ini harus disosialisasikan pada semua ibu yang mempunyai balita terutama neonatus, peran petugas kesehatan hendaknya lebih memperhatikan masalah pemenuhan tidur neonatus sehingga petugas mampu memberikan asuhan keperawatan yang paripurna, tidak hanya terbatas pada tindakan pendidikan kesehatan saja tetapi memberi contoh cara pijat bayi yang benar sehingga ibu dapat mempraktekkan pijat bayi di rumah, pemberian leaflet yang disertai gambar tentunya jauh lebih dipahami ibu daripada sekedar pendidikan kesehatan saja.

\section{Kesimpulan}

1. Pemenuhan kebutuhan tidur neonatus sebelum dilakukan pijat bayi dengan aroma terapi bunga lavender di Posyandu Melati Mojoroto Kediri didapatkan 9 responden $(69,23 \%)$ tidak terpenuhi kebutuhan tidurnya.

2. Pemenuhan kebutuhan tidur neonatus sesudah diberikan pijat bayi dengan terapi aroma bunga lavender di Posyandu Melati Mojoroto Kediri didapatkan 12 responden (92\%) terpenuhi kebutuhan tidurnya.

3. Hasil uji $t$-test nilai p $0,001<0,05$, maka ada pengaruh pijat bayi dengan aroma terapi bunga lavender terhadap pemenuhan kebutuhan tidur neonatus di Posyandu Melati Mojoroto Kediri.

\section{Saran}

1. Bagi Responden

Hendaknya dilaksanakan pemijatan pada bayi dengan teratur sehingga terpenuhi kebutuhan tidur yang akhirnya bayi dapat tumbuh dan berkembang sesuai umurnya.

2. Bagi Perawat

Hendaknya dapat menjadikan acuan dalam meningkatkan tampilan perawat dalam memberikan asuhan keperawatan yang berfokus pada pemenuhan kebutuhan tidur neonatus tentang pentingnya pijat bayi.

3. Bagi Pelayanan Keperawatan

Dapat mempertahankan dan berupaya untuk lebih meningkatkan dan memberi contoh cara pijat bayi yang benar sehingga dapat memberikan asuhan keperawatan yang paripurna.

4. Bagi Profesi

Hendaknya penelitian ini dapat meningkatkan khasanah keperawatan terhadap pemenuhan kebutuhan tidur neonatus.

5. Bagi Peneliti lain

Diharapkan bagi peneliti selanjutnya hasil penelitian ini dapat digunakan sebagai dasar dalam melaksanakan penelitian lebih lanjut dan lebih luas guna mengembangkan ilmu keperawatan yang berkaitan dengan pijat bayi untuk memenuhi kebutuhan tidur bayi

\section{DAFTAR PUSTAKA}

Arikunto, Suharsimi. (2006). Prosedur Penelitian Suatu Pendekatan Praktik. Jakarta:Rineke Cipta.

Efendi. (2011). Peran Ibu. http://www.blogspot.com. (Diunduh tanggal 12 Juni 2011, jam 18.00)

Heath, Alan, dkk. (2007). Baby Massage. Jakarta: PT Dian Rakyat 
Hidayat,A.Aziz Alimul. (2007). Riset Keperawatan Dan Teknik Penulisan Ilmiah. Jakarta: Salemba Medika

Nikita. (2011). Panduan Tumbuh Kembang Neonatus. http://www.mail-archive.com. (diunduh tanggal 12 Juni 2011), jam 18.30)

Notoatmodjo, S. (2005). Metodologi Penelitian Kesehatan. Jakarta: Rineka Cipta

Nursalam. (2003). Konsep Dan Penerapan Metodologi Penelitian Ilmu Keperawatan. Jakarta: EGC

Roesli, Utami. (2001). Pedoman Pijat Bayi Prematur dan Bayi Usia 0-3 bulan. Jakarta:Trubus Agriwidya

Suddart, Brunner. (2001). Buku Ajar Keperawatan Medikal Bedah. Vol.II. Jakarta: EGC

Sugiyono. (2009). Statistik Untuk Penelitian Dan Aplikasinya SPSS 11,5 For Windows. Bandung: Alfabeta

Soetjiningsih. (2004). Tumbuh balita dan Permasalahannya. Jakarta: EGC

Tim Gaya Hidup Sehat. (2002). Aroma Alami Untuk Kehidupan. Jakarta: Gramedia 